\title{
THE EFFECT OF COVID-19 PANDEMIC ON THE FUNCTIONING OF A SURGICAL CLINIC: SINGLE CENTRE EXPERIENCE IN TURKEY
}

\author{
Ferahman Sina, ${ }^{1}$ Donmez Turgut, ${ }^{1}$ Surek Ahmet, ${ }^{1}$ Akarsu Cevher, ${ }^{1}$ Aydin Husnu, ${ }^{1}$ \\ Seyit Hakan, ${ }^{1}$ Ozcevik Halim, ${ }^{2}$ Tecir Harun, ${ }^{1}$ Karabulut Mehmet $^{1}$ \\ ${ }^{1}$ Bakirkoy Dr. Sadi Konuk Training and Research Hospital, Department of General Surgery, Istanbul, Turkey \\ ${ }^{2}$ Istanbul Provincial Health Directorate, Department of General Surgery, Istanbul, Turkey
}

Primljen/Received 04. 12. 2020. god.

Abstract: Introduction: Covid-19 is a viral epidemic disease that causes serious health problems and death worldwide. The rapid expansion of Covid-19 infection led to the disruption of healthcare services and radical re-organisation of healthcare resources due to the healthcare workers' infection.

Aim: This clinical study investigated the effects of Covid-19 infection on emergency and elective cases in our general surgery clinic.

Material and methods: We retrospectively analysed the clinical data of 195 patients who underwent elective (Group Elective) and emergency (Group Emergency) surgery during the Covid-19 incubation period in the Bakırköy Dr. Sadi Konuk Training and Research Hospital between March 11 - May 18, 2020. Demographic features, symptoms, surgical diagnoses, surgical methods, complications, duration of surgery, length of hospital stay and mortality, the status of Covid-19 of all patients were recorded.

Results: 195 patients, including emergency and elective surgery cases, were operated on (104 and 91, respectively). The incidence of Covid-19 infection was $5.49 \%$ in patients scheduled for elective surgery and $4.8 \%$ in patients operated urgently, and all developed in the postoperative period. Two patients with emergency surgery died of respiratory failure, their mean age was 51 years. Two of 104 emergency-operated patients were positive from Covid-19 (1.92\%) at the time of admission. Eighteen medical staff and nurses got Covid-19 infections.

Conclusions: Due to the rapid spread of Covid-19 infection, early precautions must be taken in surgical clinics to guarantee the safety of patients all healthcare providers, and personnel.

Key Words: Covid-19, General Surgery, Emergency, Operation.
Prihvaćen/Accepted 25. 01. 2021. god.

\section{INTRODUCTION}

Following the notification of the first serious coronavirus disease 2019 (Covid-19) cases in Wuhan, China in December 2019, the virus began to spread all over the world, and this Covid-19 viral outbreak was declared a pandemic by the World Health Organisation (WHO) on March 11 (1). Studies show that $\%$ of the population are asymptomatic carriers of Covid-19 and these viruses are responsible for about $5 \%$ to $10 \%$ of acute respiratory infections $(2,3)$. Patients initially present with the complaint of fever with or without pulmonary symptoms, but varying degrees of pulmonary pathologies are detected with thorax computed tomography (CT) $(4,5,6)$. Although it is mostly a common and mild disease in patients, approximately $15-20 \%$ of patients develop severe disease, and oxygenation is required in this severely ill group (6). This severe group has a high mortality rate and co-morbidities such as advanced age, diabetes mellitus, and medical procedures (such as endoscopic procedures, angiography procedures, and elective surgeons who operate and are infected in a hospital setting) increase mortality rate (6). The pathogenic mechanism leading to pneumonia appears complex. Data from studies show that viral infection causes an excessive immune reaction in the host. It produces a reaction that leads to extensive tissue damage, defined as a "cytokine release storm" (CRS). The main factor in this storm is interleukin 6 (IL-6). IL-6 is produced by activated leukocytes and acts on a large number of cells and tissues. It also stimulates the production of acute-phase proteins and plays an important role in thermoregulation, bone structure, and functionality of the central nervous system. IL-6 has anti-inflammatory effects in addition to its pro-inflammatory role. However, IL-6 also increas- 
es in inflammatory diseases, infections, autoimmune disorders, cardiovascular diseases, and some types of cancer. It is also seen in the pathogenesis of CRS, an acute systemic inflammatory syndrome characterised by fever and multiple organ failure (7).

Governments are working hard to take measures to prevent the devastating effects of the Covid-19 pandemic. Many uncertainties persist regarding both the virus-host interaction and the trend of the outbreaking of the virus, such as when the outbreak will reach its peak, and the dangers of the 2nd or 3rd wave epidemics. Like all countries in the world, the Republic of Turkey Ministry of Health took extraordinary measures to get viral spread under control. As of March 11, 2020, when the first case was reported in Turkey, travel restrictions were introduced for all countries of the world where the epidemic had caused serious destruction, and then to other countries because of the spread of the epidemic. Elective surgical operations were stopped in all hospitals except for cancer patients. As a result, all surgical services in the surgical department were stopped, except for endoscopy and cancer cases with outpatient and oncological emergencies. However, the emergency room continued to accept surgical patients. All surgical branch physicians joined the Covid-19 treatment and follow-up team.

In parallel with the progressive increase in Covid-19 cases and lung findings consistent with Covid-19 in our society, patients with suspected Covid-19 infection started to be detected in the general surgery service parallel with the increase in consultations in the emergency department. Initial infection cases were recorded among surgical service nurses.

In this study, descriptive analysis was conducted about the impact of the first two months of the Covid-19 pandemic in the General Surgery department of a tertiary hospital in Istanbul (Turkey). The aim of this study was to analyse the surgical cases in the general surgical ward when the incidence of the Covid-19 epidemic increased in general population, to investigate the effect of the infection on the health services, and to evaluate the effect of the measures taken.

\section{MATERIAL AND METHODS}

Between March 11 and May 18, data were prospectively collected from the General Surgery service in Bakırköy Dr. Sadi Konuk Training and Research Hospital from patients in a clinic confirmed with Covid-19 and among surgeons with confirmed Covid-19. It is a 380-bed state hospital. There are 18 surgical residents, eight doctors, one professor, and 15 general surgery specialists in the General Surgery and Digestive Surgery Service.
This study was carried out in accordance with the 1964 Helsinki Declaration and its recent amendments. Written consent was obtained from all participants. Permission was obtained from the local ethics committee (Ref. Nr: 2020-09) and the Ministry of Health Scientific Research Institution (Ref. Nr: 2020-0506T09 16_49).

The presence of at least one of the following symptoms: the onset of cough, shortness of breath, throat pain, chest pain, anosmia, muscle pain, or fever was accepted as compatible with Covid-19 (1). Suspected cases were confirmed with the reverse transcription-polymerase chain reaction (RT-PCR) technique using a nasopharyngeal swab sample (according to the method of the microbiology laboratory in the hospital). Patients and doctors with negative RT-PCR but maintaining clinical compatibility with Covid-19 had repeated their diagnostic tests with RTPCR. Radiological signs compatible with Covid-19 were ground-glass appearance, diffuse alveolar consolidation pattern, bilateral patchy shading, and cobblestone pattern which were considered consistent with Covid-19 pneumonia. RT-PCR $(+)$ or thoracic CT Covid-19 pneumonia findings $(+)$ patients with any $(+)$ received Covid-19 diagnosis and treatment.

Patients who were operated on during the Covid -19 pandemic in the General Surgery Clinic were divided into two groups as planned surgery (group elective) and emergency surgery (group emergency). Demographic features, symptoms, surgical diagnosis, surgical methods, complications, duration of surgery, length of hospital stay, and mortality of all patients were recorded. Laboratory and radiological evaluations were recorded.

\section{Statistical analysis}

Statistical analysis was performed with JMP $®$ software version 9.0.1 (SAS ${ }^{\circledR}$ Institute, Inc, Cary, North Carolina, USA). Patient characteristics were analysed via descriptive statistics. Continuous variables were expressed as mean $\pm \mathrm{SD}$ or median and interquartile ranges. Categorical variables were expressed as frequencies and percentages. Comparison of parametric continuous variables was performed using Student's t-test. The Mann-Whitney U test was used for non-parametric continuous variables. The Chi-square test was used for the comparison of categorical variables. p-values of 0.05 or less were considered statistically significant.

\section{RESULTS}

The usual healthcare service continued from March 11 to March 31, and surgical procedures for benign pa- 
Table 1. Patient characteristics and operative results

\begin{tabular}{|c|c|c|c|}
\hline & $\begin{array}{c}\text { Emergency surgery } \\
\text { (n: 104) }\end{array}$ & $\begin{array}{l}\text { Elective surgery } \\
\text { (n: 91) }\end{array}$ & p value \\
\hline Age $(y)($ mean \pm SD $)$ & $43.82 \pm 19.45$ & $54.53 \pm 14.33$ & $<0.001$ \\
\hline Gender Female/male & $54 / 50$ & $42 / 49$ & 0.421 \\
\hline BMI* $^{*} \mathrm{~kg} / \mathrm{m} 2($ mean \pm SD) & $26.24 \pm 2.92$ & $26.73 \pm 3.21$ & 0.192 \\
\hline \multicolumn{4}{|l|}{ ASA $^{* *}$ score } \\
\hline $\mathbf{I}$ & 44 & 11 & \multirow{4}{*}{$<0.001$} \\
\hline II & 34 & 44 & \\
\hline III & 23 & 32 & \\
\hline IV & 3 & 4 & \\
\hline Comorbidity & 37 & 66 & \multirow{7}{*}{$<0.001$} \\
\hline Hypertension & 18 & 31 & \\
\hline Diabetes Mellitus & 9 & 19 & \\
\hline Cardiovascular disease & 5 & 9 & \\
\hline Cerebrovascular disease & 3 & 1 & \\
\hline COPD $^{\dagger}$ & 2 & 5 & \\
\hline Chronic kidney disease & 0 & 1 & \\
\hline Surgical Time $(\min )($ mean \pm SD $)$ & $62.14 \pm 26.43$ & $152.24 \pm 107.63$ & $<0.001$ \\
\hline Hospital stay (day) (mean \pm SD) & $4.62 \pm 0.56$ & $5.86 \pm 0.6$ & 0.156 \\
\hline Preoperative covid-19 (+) & $2(1.92 \%)$ & 0 & 0.098 \\
\hline Postoperative covid-19 (+) & $5(4.80 \%)$ & $5(5.49 \%)$ & 0.416 \\
\hline Mortality & $6(5.76 \%)$ & $8(8.79 \%)$ & \multirow{3}{*}{0.500} \\
\hline Covid-19 (+) & $2(1.92 \%)$ & 0 & \\
\hline Covid-19 (-) & $4(3.84 \%)$ & $8(8.79 \%)$ & \\
\hline
\end{tabular}

*BMI: Body mass index, ${ }^{* *}$ ASA: American Society of Anesthesiologists, ${ }^{\dagger}$ COPD: Chronic obstructive pulmonary disease.

thologies were suspended from March 31. From March 31, patients with oncological pathology and emergency surgical cases were operated on.

The demographic data of the patients are given in Table 1 . There was no statistically significant difference between the two groups in terms of gender, body mass index, and length of hospital stay. A statistically significant difference was detected between the two groups in terms of the American Society of Anesthesiologists (ASA) score and concomitant diseases ( $\mathrm{p}<$ 0.001) (Table 1).

Between March 11 - May 18, 2020, 195 patients were operated on in the General Surgery Service, 104 were urgent and 91 were planned surgical cases (Table 2).

In emergency cases, laparoscopic appendectomy was the most performed surgery due to acute appendicitis, and emergency cases due to colon cancer were identified in second place. Among the planned surgeries, the most common surgery was identified as colorectal cancer cases (Table 2).

Emergency cases (colostomy necrosis, acute perforated diverticulitis, multiple small bowel perfo- rations, toxic megacolon, and acute mesenteric ischemia) and elective cases (morbid obesity, splenectomies, adrenal adenoma, clastic skin cancer, hydatid cysts, and nutrition gastrostomy) were examined.

The age group was significantly higher in the elective surgery group than in the emergency surgery group $(\mathrm{p}<0.001)$ (Table 1$)$.

The mean age of Covid-19 positive patients undergoing planned surgery was 54.5 years, and the mean age of patients undergoing emergency surgery was 43.8 years $(\mathrm{p}<0.001)$. Of infected patients, $56.25 \%$ were male. The most common comorbidities among these patients were hypertension (HT), diabetes mellitus (DM), and cardiovascular diseases, respectively (Table 1).

In terms of the duration of surgery between the two groups, it was found to be significantly higher in the elective surgery group compared to the emergency surgery group $(\mathrm{p}<0.001)$ (Table 1$)$.

There was no statistically significant difference between the two groups in terms of contracting postoperative Covid-19 $(+)$ disease and mortality $(\mathrm{p}=$ 
Table 2. Distribution of cases in covid-19 pandemic

\begin{tabular}{|l|c|c|c|}
\hline \multicolumn{1}{|c|}{ Variable } & $\begin{array}{c}\text { Emergency surgery } \\
\text { (n: 104) }\end{array}$ & $\begin{array}{c}\text { Elective surgery } \\
\text { (n: 91) }\end{array}$ & $\begin{array}{c}\text { Total } \\
\text { (n: 195) }\end{array}$ \\
\hline Cholelithiasis (LC) & 5 & 11 & 16 \\
\hline Abdominal wall hernia & 5 & 4 & 16 \\
\hline Open technique & 5 & 4 & 9 \\
\hline Laparoscopic & 0 & 20 & 7 \\
\hline Colorectal cancer & 13 & 12 & 23 \\
\hline Open technique & 13 & 8 & 8 \\
\hline Laparoscopic/Robotic & 0 & 4 & 5 \\
\hline Gastric Cancer (Open technique) & 1 & - & 11 \\
\hline Peptic ulcus perforation & 11 & - & 6 \\
\hline Open technique & 6 & - & 5 \\
\hline Laparoscopic & 5 & - & 46 \\
\hline Acute Appendicitis (LA) (UAA/CAA) & $36 / 10$ & 4 & 4 \\
\hline Pancreas cancer (Open Technique) & - & 16 & 16 \\
\hline Breast cancer & - & 9 & 9 \\
\hline Thyroid Cancer & - & 2 & 2 \\
\hline Retroperitoneal sarcoma & - & - & 4 \\
\hline Fournier gangrene & 4 & 7 & 7 \\
\hline Benign anorectal disease & - & - & 2 \\
\hline Gunshot injury & 2 & - & 3 \\
\hline Blunt abdominal trauma & 3 & - & 5 \\
\hline Intraabdominal knife injury & 5 & & 15 \\
\hline Others & 8 & 7 & \\
\hline
\end{tabular}

${ }^{*} \mathrm{LC}$ : Laparoscopic cholecystectomy, ${ }^{\dagger} \mathrm{LA}$ : Laparoscopic appendectomy, ${ }^{\ddagger}$ UAA: uncomplicated acute appendicitis, ${ }^{\S} \mathrm{CAA}$ : complicated acute appendicitis.

$0.416, \mathrm{p}=0.50$, respectively) RT-PCR $(+)$ and thorax CT $(+)$ were two or two $(+)$, and two of seven patients requiring emergency surgery were preoperatively Covid-19 (+). The first patient, a 49-year-old male with diabetes mellitus disease, was operated on due to Fournier gangrene in the bilateral inguinal region with RT-PCR + and thorax CT (-) ASA II. The patient, who was followed up in the postoperative ward, received Covid-19 treatment for seven days and vacuum-assisted wound closure (VAC) was applied three times. He was discharged after healing. In the second patient, a laparoscopic Miles operation was performed in October 2019 because of an anal canal tumor, and the ASA III case had segmented colon resection with end colostomy operation due to necrosis. The patient had preoperative thorax CT (+), RT-PCR (-) and Covid-19 treatment was additionally applied. He was discharged on the 10th day with healing.

In the postoperative period, for 102 patients undergoing other emergency surgeries, one patient had RT-PCR $(+)$ and thorax CT $(+)$, three patients had
Thorax CT $(+)$ and one patient had RT-PCR $(+)$ for Covid-19 (7.14\%). Two patients died in the postoperative intensive care unit (ICU). The first patient, a 51-year-old female patient, who was ASA IV, underwent perforation repair + mentoplasty due to peptic ulcer perforation(PUP), followed in ICU on the third day, thorax CT (+) - RT-PCR (-) and died on the 5th day. The second patient, a 51-year-old male patient with ASA III, underwent massive small bowel resection due to mesenteric panniculitis + multiple small bowel perforations as acute abdomen (Table 1).

In the emergency surgery group, the other three patients who developed a Covid-19 infection after surgery were discharged with healing after receiving additional treatment (Table 3).

Covid-19 was present in five $(5.49 \%)$ of 91 patients who underwent planned surgery (Table 1). Between March 11 and May 15, 17 patients who underwent scheduled hospitalisation showed respiratory symptoms and fever between the 2nd and 8th postoperative days, all of them received RT-PCR and thorax CT, and 
Table 3. Data of patients with covid-19 infection in the postoperative period

\begin{tabular}{|c|c|c|c|c|c|c|c|c|c|c|c|}
\hline & $\begin{array}{c}\text { Patient } \\
1\end{array}$ & $\begin{array}{c}\text { Patient } \\
2\end{array}$ & $\begin{array}{c}\text { Patient } \\
3\end{array}$ & $\begin{array}{c}\text { Patient } \\
4\end{array}$ & $\begin{array}{c}\text { Patient } \\
5\end{array}$ & $\begin{array}{c}\text { Patient } \\
6\end{array}$ & $\begin{array}{c}\text { Patient } \\
7\end{array}$ & $\begin{array}{c}\text { Patient } \\
8\end{array}$ & $\begin{array}{l}\text { Patient } \\
9\end{array}$ & $\begin{array}{c}\text { Patient } \\
10\end{array}$ & $\begin{array}{l}\text { No } \\
(\%)\end{array}$ \\
\hline Age, years & 51 & 86 & 61 & 56 & 51 & 55 & 56 & 62 & 67 & 58 & $\mathrm{~N} / \mathrm{A}$ \\
\hline Gender, Female/male & Female & Female & Male & Male & Male & Male & Male & Female & Female & Male & $\mathrm{N} / \mathrm{A}$ \\
\hline \multicolumn{12}{|l|}{ Comorbidities } \\
\hline Cardiovascul. disease & No & No & No & No & Yes & No & No & No & No & No & $1(10)$ \\
\hline Malignancy & Yes & Yes & Yes & Yes & No & Yes & Yes & Yes & Yes & Yes & $9(90)$ \\
\hline Hypertension & No & Yes & Yes & Yes & No & Yes & No & No & No & Yes & $5(50)$ \\
\hline Diabetes & Yes & Yes & Yes & Yes & No & Yes & Yes & Yes & Yes & Yes & $9(90)$ \\
\hline Cerebrovascul disease & No & Yes & No & No & No & No & No & No & No & No & $1(10)$ \\
\hline COPD & No & Yes & No & No & No & No & No & No & No & No & $1(10)$ \\
\hline ASA Class & IV & IV & III & III & III & III & III & III & III & III & $\mathrm{N} / \mathrm{A}$ \\
\hline Diagnosis & PUP & $\mathrm{GC}$ & CP-SCC & $\mathrm{OCC}$ & MSBP & DRC & SCC-CVF & PHC & DPC & $\mathrm{DCC}$ & $\mathrm{N} / \mathrm{A}$ \\
\hline Surgical type & Emergency & Emergency & Emergency & Emergency & Emergency & Elective & Emergency & Elective & Elective & Elective & $\mathrm{N} / \mathrm{A}$ \\
\hline Surgical treatment & GR-0 & DSG & SCR-H & LC & MSBR & RLAR & SCR-VR & Whipple & DP-S & LH & $\mathrm{N} / \mathrm{A}$ \\
\hline Surgical time, min & 74 & 190 & 145 & 65 & 175 & 162 & 286 & 285 & 180 & 134 & $\mathrm{~N} / \mathrm{A}$ \\
\hline ICU & Yes & Yes & No & No & Yes & No & Yes & Yes & Yes & No & $6(60)$ \\
\hline Day of first sypmtom & 3 & 4 & 5 & 5 & 2 & 6 & 8 & 5 & 3 & 3 & $\mathrm{~N} / \mathrm{A}$ \\
\hline First symptom or sign & Fever & Cough & Cough & Cough & Fever & Fever & Cough & Fever & Cough & Fever & $\mathrm{N} / \mathrm{A}$ \\
\hline RT-PCR test & Negative & Positive & Negative & Negative & Positive & Negative & Positive & Positive & Positive & Positive & $6(60)$ \\
\hline Toraks BT (Covid-19) & Positive & Positive & Positive & Positive & Negative & Positive & Positive & Negative & Negative & Positive & $7(70)$ \\
\hline \multicolumn{12}{|l|}{ Complications } \\
\hline Respiratory failure & Yes & Yes & No & No & Yes & No & Yes & Yes & Yes & No & $6(60)$ \\
\hline ARDS & No & No & No & No & Yes & No & No & No & No & No & $1(10)$ \\
\hline Shock & Yes & No & No & No & Yes & No & No & No & No & No & $2(20)$ \\
\hline Arrhythmia & Yes & No & No & No & No & No & No & No & Yes & No & $2(20)$ \\
\hline Secondary infection & No & No & Yes & Yes & No & Yes & Yes & No & No & No & $4(40)$ \\
\hline Mortality & Yes & No & No & No & No & No & No & No & No & No & $2(20)$ \\
\hline Day of death & 5 & - & - & - & 8 & - & - & - & - & - & $\mathrm{N} / \mathrm{A}$ \\
\hline Hospital stay (day) & - & 12 & 12 & 13 & - & 14 & 22 & 15 & 10 & 10 & $\mathrm{~N} / \mathrm{A}$ \\
\hline
\end{tabular}

Abbreviations: COPD; Chronic obstructive pulmonary disease, ASA Class; American society of anesthesiologists classification, PUP; Peptic ulcus perforation, GC; Gastric cancer, CP-SCC; Colon perforation with sigmoid colon cancer, OCC; Obstructive colon cancer, MSBP; Multipl small bowel perforation, DRC; Distal rectum cancer, SCC-CVF; Sigmoid colon cancer with colovesical fistula, PHC; Pancreas head cancer, DPC; Distal pancreas cancer, DCC; Descenden colon cancer, DSG; Distal subtotal gastrectomy, SCR-H; Sigmoid colon resection + hartman procedure; GR-H;Grahamrafi + omentoplasty, LC; Loop colostomy, MSBR; Massive small bowel resection, RLAR; Robotic low anterior resection, SCR-VR; Sigmoid colo nresection + near total vesical resection, DP-S; Distal pancreatectomy + splenectomy, LH; Left hemicolectomy, ICU; Intensive Care Unit, ARDS; Acute Respiratory Distress Syndrome.

the patients used surgical masks from the moment of suspicion. In five cases, Covid-19 infection was confirmed (RT-PCR and thorax CT). The first patient, a 56-year-old ASA III male patient underwent colon resection + nearly total bladder resection + ileal bladder surgery for a sigmoid tumor with colovesical fistula. On the 5thpostoperative day, an intra-abdominal abscess was repeated, and on the 8th postoperative day RT-PCR $(+) /$ thorax CT $(+)$, and Covid-19 treatment was started. He was discharged on the 22 nd postoperative day. The other four patients who developed Covid-19 infection after surgery in the elective group were discharged with healing after receiving additional treatment (Table 3 ).

Confirmed Covid-19 patients were treated with an infection and pneumology team in a separate isolated room with clinical follow-up according to hospital protocol. None of these patients had to receive intensive care because of clinical deterioration and five patients were discharged.

Nineteen days after low anterior resection surgery due to rectum cancer, a patient aged 74 years was admitted with symptoms of fever and cough, and was 
hospitalised due to bilateral Covid-19 pneumonia with RT-PCR (+) and Thorax CT (+) and treated in the infection clinic. This contamination was probably achieved in the community because it was beyond the maximum 14-day incubation period defined for Covid-19.

From March 11 to May 18, 104 emergency surgical interventions were carried out. Interventions were performed in 10 patients due to perforated appendicitis, 11 patients due to PUP, 4 patients due to large bowel tumor perforation, one patient for bowel perforation, and one patient for diverticulitis perforation. In other words, $26 \%$ of 104 patients who underwent emergency surgery since March 11 had a presentation of peritonitis at diagnosis.

During this period, consultations for Covid-19 patients with potential surgical pathology were also performed. Seven patients were evaluated: two had acute cholecystitis and two had appendicular plastron treated conservatively with antibiotics. The hernias of two patients who had incarcerated inguinal hernias were rejected. Conservative treatment was performed for one patient with a hematoma of the rectus sheath. Therefore, conservative treatment was provided for all patients with Covid-19 infection who were potentially hospitalised with surgical pathology.

The effects of the Covid-19 pandemic on healthcare workers were examined in the General Surgery Service and the operating room. These included five ward nurses, two operating room nurses, four anaesthesia residents, two anaesthesiologists, three operating room personnel, and two ward personnel. Eight $(50 \%)$ of these employees were hospitalised and treated because they had serious problems. They were discharged with healing. Ten others spent the duration with Covid-19 in their homes asymptomatically.

Serious measures were taken since March 11. These measures include the suspension of clinical sessions and face-to-face multidisciplinary committees, wearing protective equipment and hospital shoes, surgical masks, face visors, avoiding touching the face, washing common work surfaces and washing in and out of the hospital before and after each patient. Washing hands with hydroalcoholic solution was tightly applied even when wearing gloves.

\section{DISCUSSION}

As an epidemic, the Covid-19 pandemic originated in Wuhan city in the People's Republic of China, and spread to Europe and the entire world, especially in neighbouring countries. After the detection of Covid-19 in Europe, Iran and Saudi Arabia in February, security and health screenings were increased at airports and border gates.
After the first identification of a citizen, who visited Europe, in Istanbul on March 11, education was interrupted, from early childhood education to university education, and the distant education program was started on March 16.

From March 11, when Covid-19 infection was announced, to May 18, 150.593 cases and 4.171 deaths were reported in the 80 million population in our country. Istanbul is the most populous city in the country with a population of 16 million, and it is the city where $60 \%$ of Covid- 19 cases and deaths occurred due to being a center of tourism and trade.

In addition, all face-to-face meetings in the Bakırköy Dr. Sadi Konuk Hospital and all other hospitals were suspended from March 11 and these meetings were held by teleconference. Surgical interventions and surgeries planned for benign pathologies were suspended as of March 31 (8), and emergency or non-oncological consultation of our general surgery clinic was canceled. Precautionary measures were increased among hospital health and administrative staff. All appointments and procedures, except for emergency procedures, were canceled in the endoscopy section.

As of March 31, elective surgeries were planned for cancer patients who had the highest priority cases due to the risk of early complications and did not show fever or active respiratory pathology at the time of admission or in the previous days, with a negative Covid-19 test and no direct contact with Covid-19 (+) cases.

The Covid-19 epidemic has had a major impact on health worldwide. A) The importance of quarantine and home isolation of healthcare workers after Covid-19 transmission reduced the current workforce in healthcare and assistance among branches, B) There were significant reductions in the number of patients going to the emergency department during the epidemic period. Real emergency patients with emergency surgical pathology (appendicitis, cholecystitis, diverticulitis etc.) and with more or complex symptoms, reduced burden in surgical wards. C) There were reductions in planned surgical activity in cancer patients, selecting all cases with risk of obstruction or perforation and all elective surgeries for benign pathology were suspended (10).

In our highly suspected or confirmed Covid-19 patient series, five planned surgeries and seven urgent surgeries were performed. Two of the patients operated urgently died. The 1st patient, a 51-year-old female, was ASA IV with open raphy + omentoplasty surgery due to PUP and died on the 5th postoperative day in the ICU. The other patient who was operated due to acute abdomen and was treated in the ICU died on the 8th day. Other patients who were operated surgically 
and operated on a planned basis had varying respiratory symptoms, but all responded to medical treatment in a regular hospital room without need for orotracheal intubation.

We cannot conclude that Covid-19 infection is the differential element between both patient groups, because the mean age, surgical diagnosis, and clinical severity of each group do not allow us to compare both groups.

In case of confrontation with the Covid-19 pandemic, it is preferable to turn to existing alternatives (antibiotic therapy, percutaneous drainage, cholecystitis, stent placement or delayed surgery) until the disease is less common for both emergency surgery and elective cancer patients $(10,11)$.

In hospitals serving in a region with high Covid-19 cases, it is recommended that all patients be scanned preoperatively with RT-PCR and/or chest CT for cases undergoing elective cancer surgery and emergency surgery (12). In this epidemic period, it is important for the patient to get the best available treatment (percutaneous drainage, antibiotic therapy, laparoscopy or laparotomy) as well as the necessary protective measures (8). However, there is a significant problem regarding open or laparoscopic method for the selection of the surgical technique for the patient. Since CO2 pneumoperitoneum is used in robotic, laparoscopic and single-port techniques, it poses serious risks for both the patient and the medical team. This is because aerosols formed during the operation tend to concentrate in the abdominal cavity because of the low gas mobility in pneumoperitoneum. Sudden release of trocar valves, airtight instrument replacement, and even small abdominal extraction incisions can expose the medical team to pneumoperitoneum aerosols. The risk due to laparoscopy is definitely higher than traditional open surgery $(13,14)$. If the operation is to be performed laparoscopically, it is recommended that the patient is kept at a low pressure and in trendelenburg oscillation as much as possible (14). In our clinic, we performed the laparoscopic technique in cases of acute appendicitis and acute cholecystitis and left the patient in trendelenburg position and low pressure $(8 \mathrm{mmHg})$. While we performed emergency and elective surgery for colon cancer with the open method, we performed robotic surgery for elective rectum cancer cases. We did not detect Covid-19 cases in any of these patients.

In our study, our mortality was $12(6.15 \%)$ patients with seven $(3.58 \%)$ patients among emergency cases and five $(2.57 \%)$ patients among elective cases (Table 1). Among emergency cases, two patients with postoperative Covid-19 (+) died. The first of these patients was a 51 -year-old operated for breast cancer who underwent omentoplasty due to PUP and had ASA IV with bone, lung and liver metastases. The other patient had a massive small bowel resection due to multiple small bowel perorations with connective tissue disease. We do not think that these patients died primarily due to Covid-19. Preoperative and postoperative Covid-19 (-) in patients who died were elective cases.

There was no death among our Covid $(+)$ patients in the postoperative period, who were operated electively. In a clinical study conducted by Lei et al., seven patients out of 34 patients with Covid-19 (+) after emergency and elective surgery were reported to die in the Covid-19 pandemic (8). However, since there is no data on the total number of surgeries performed in the hospital, no data on Covid-19 (+) transmission were included. In our study, despite our high case count, we think that the Covid-19 transmission rate and low mortality indicate the effectiveness of the measures and treatment used in our country.

The main purpose of patient safety is to intervene with patients who may have worsened respiratory conditions with oral intubation and Covid-19, and to prevent virus contamination of patients without Covid-19 in the postoperative period (15).

During this period when the peak of Covid-19 cases occurred, all basic measures were applied to protect healthcare workers. As a result of all the precautions taken, Covid-19 (+) was not detected in any faculty, specialist doctor and resident doctors among the surgeons in the general surgery department. However, five ward nurses and two ward personnel were Covid-19 positive. After the first confirmed cases in our health service, strict compliance with individual protection measures, disinfection of common areas and suspension of doctor meetings were enforced. These measures reduced the incidence of new cases, along with the isolation of all healthcare workers at home with suspected symptoms or confirmed infection.

Infection of health personnel is an additional cause of concern for the management of this social and health crisis (16). Action instructions were prepared for confirmed or very suspicious patients with Covid-19 infection. We all know what precautions should be applied in General Surgery wards based on available literature and subjects to review as the pandemic develops in our country in general $(12,17)$.

\section{CONCLUSION}

The Covid-19 outbreak has a major impact on health systems worldwide. This epidemic has resulted in reorganisation of existing resources and questioning health systems. To cope with the rapid spread of the coronavirus and the severity of the clinical tableau it 
produces, General Surgery services need to reconsider surgical and healthcare activities.

Since the beginning of the Covid-19 cases, no infection has been detected $(0 \%)$ as a reward for our strict preventative measures among our surgeons and assistants. Ten $(5.12 \%)$ of postoperative emergency and elective patients had COVID-19 infection. Death was concentrated in patients with high ASA scores with emergency surgical pathology.

Acknowledgment: None.

Conflict of Interests: The authors declare that there are no conflicts of interest related to this article.

Funding: None

\title{
Licensing
}

This work is licensed under a Creative Commons Attribution 4.0 International (CC BY 4.0) License Sažetak

\section{UTICAJ PANDEMIJE KOVID-19 NA FUNKCIONISANJE HIRURŠKE KLINIKE: ISKUSTVO JEDNOG CENTRA U TURSKOJ}

\author{
Ferahman Sina, ${ }^{1}$ Donmez Turgut, ${ }^{1}$ Surek Ahmet, ${ }^{1}$ Akarsu Cevher, ${ }^{1}$ Aydin Husnu, ${ }^{1}$ Seyit Hakan, ${ }^{1}$ \\ Ozcevik Halim, ${ }^{2}$ Tecir Harun, ${ }^{1}$ Karabulut Mehmet $^{1}$ \\ ${ }^{1}$ Bakirkoy Dr Sadi Konuk Training and Research Hospital, Department of General Surgery, Istanbul, Turkey \\ ${ }^{2}$ Istanbul Provincial Health Directorate, Department of General Surgery, Istanbul, Turkey
}

Uvod: Kovid-19 je virusna epidemija koja uzrokuje ozbiljne zdravstvene probleme i smrt širom sveta. Brzo širenje infekcije Kovid-19 dovelo je do poremećaja u zdravstvenim ustanovama i radikalne reorganizacije zdravstvenih resursa zbog zaraze zdravstvenih radnika.

Cilj: U našoj kliničkoj studiji istražili smo posledice infekcije Kovid-19 na hitne i elektivne slučajeve u našoj Klinici za opštu hirurgiju.

Materijal i metode: Retrospektivno smo analizirali kliničke podatke 195 pacijenata koji su bili podvrgnuti elektivnoj (Grupa Elektivna) i hitnoj (Grupa Hitna) operaciji tokom perioda inkubacije Kovid-19 u Bolnici za obuku i istraživanje Bakırkoi Dr Sadi Konuk od 11. marta do 18. maja 2020. Zabeležene su demografske karakteristike, simptomi, hirurške dijagnoze, hirurške metode, komplikacije, trajanje operacije, dužina boravka u bolnici i mortalitet, status Kovid-19 svih pacijenata.

Rezultati: Operisano je 195 pacijenata, uključujući hitnu i elektivnu operaciju (104, odnosno 91). Incidencija infekcije Kovid-19 bila je 5,49\% kod pacijenata kojima je zakazana elektivna operacija i $4,8 \%$ kod pacijenata koji su hitno operisani, a sve su se razvile u postoperativnom periodu. Dvoje pacijenata sa hitnom operacijom umrlo je od respiratorne insuficijencije, srednje starosni dobi od 51 godinu. Dva od 104 hitno operisana pacijenta bila su pozitivna na Kovid-19 (1,92\%) u trenutku prijema. Osamnaest članova medicinskog osoblja i medicinskih sestara se inficiralo korona virusom.

Zaključci: Zbog brzog širenja infekcije Kovid-19, rane mere predostrožnosti moraju se preduzeti u hirurškim klinikama kako bi se garantovala bezbednost pacijenata, kao i svih zdravstvenih radnika i osoblja.

Ključne reči: Kovid-19, opšta hirurgija, hitna pomoć, operacija.

\section{REFERENCES}

1. Guan WJ, Ni ZY, Hu Y, Liang WH, Ou CQ, He JX, et al. Clinical characteristics of Coronavirus disease 2019 in China. N Engl J Med. 2020; 382(18): 1708-20. doi: 10.1056/ NEJMoa2002032.

2. Chan JF, To KK, Tse H, Jin DY, Yuen KY. Interspecies transmission and emergence of novel viruses: lessons from bats and birds. Trends Microbiol. 2013; 21(10): 544-55. doi: 10.1016/j.tim.2013.05.005.

3. Tian S, Hu W, Niu L, Liu H, Xu H, Xiao SY. Pulmonary pathology of early-phase 2019 novel Coronavirus (COVID-19) pneumonia in two Patients with lung cancer. J Thorac Oncol. 2020; 28(5): 700-4. doi: 10.1016/j.jtho.2020.02.010.

4. Huang C, Wang Y, Li X, Ren L, Zhao J, Hu Y, et al. Clinical features of patients infected with 2019 novel coronavirus in Wuhan, China. Lancet 2020; 395(10223): 497-506. doi: 10.1016/S0140-6736(20)30183-5.

5. Zhu N, Zhang D, Wang W, Li X, Yang B, Song J, et al. A novel Coronavirus from patients with pneumonia in China, 2019. N Engl J Med. 2020; 382(8): 727-33. doi: 10.1056/NEJMoa2001017. 
6. Wang D, Hu B, Hu C, Zhu F, Liu X, Zhang J, et al. Clinical characteristics of 138 hospitalized patients with 2019 novel Coronavirus-infected pneumonia in Wuhan, China. JAMA. 2020; 323(11): 1061-9. doi: 10.1001/jama.2020.1585. Erratum in: JAMA. 2021;325(11):1113.

7. Cascella M, Rajnik M, Cuomo A, Dulebohn SC, Di Napoli R. Features, evaluation and treatment Coronavirus (COVID-19). 2020 Apr 6. In: Stat Pearls [Internet]. Treasure Island (FL): Stat Pearls Publishing; 2020 Jan-PMID: 32150360.

8. Lei S, Jiang F, Su W, Chen C, Chen J, Mei W, et al. Clinical characteristics and outcomes of patients undergoing surgeries during the incubation period of COVID-19 infection. E Clinical Medicine. 2020; 21; 100331. doi: 10.1016/j. eclinm.2020.100331.

9. Aminian A, Safari S, Razeghian-Jahromi A, Ghorbani M, Delaney CP. COVID-19 outbreak and surgical practice: unexpected fatality in perioperative period. Ann Surg. 2020; 272(1): e27-e9. doi: 10.1097/SLA.0000000000003925.

10. Sica GS, Campanelli M, Bellato V, Monteleone G. Gastrointestinal cancer surgery and enhanced recovery after surgery (ERAS) during COVID-19 outbreak. Langenbecks Arch Surg. 2020; 405(3): 357-8. doi: 10.1007/s00423-020-01885-0.

11. Ti LK, Ang LS, Foong TW, Ng BSW. What we do when a COVID-19 patient needs an operation: operating room preparation and guidance. Can J Anaesth. 2020; 67(6): 756-8. doi: 10.1007/s12630-020-01617-4.
12. SAGES and EAES Recommendations Regarding Surgical Response to COVID-19 Crisis - SAGES [Internet] [consultado 1 Abr 2020]. https://www.sages.org/recommendations-surgical-response-covid-19.

13. Li CI, Pai JY, Chen CH. Characterization of smoke generated during the use of surgical knife in laparotomy surgeries. J Air Waste Manag Assoc. 2020; 70(3): 324-32. doi: 10.1080/10962247.2020.1717675.

14. Zeng MH, Boni L, Fingerhut A. Minimally invasive surgery and the novel Coronavirus outbreak: lessons learned in China and Italy. Ann Surg. 2020; 272(1): e5-e6. doi: 10.1097/ SLA.0000000000003924.

15. Li R, Pei S, Chen B, Song Y, Zhang T, Yang W et al. Substantial undocumented infection facilitates the rapid dissemination of novel coronavirus (SARS-CoV2). Science. 2020; 368(6490): 489-93. doi: 10.1126/science.abb3221.

16. Bedford J, Enria D, Giesecke J, Heymann DL, Ihekweazu C, Kobinger G et al. COVID-19: towards controlling of a pandemic. Lancet. 2020; 395(10229): 1015-18. doi: 10.1016/ S0140-6736(20)30673-5.

17. Zhang Z, Liu S, Xiang M, Li S, Zhao D, Huang C et al. Protecting healthcare personnel from 2019-nCoV infection risks: lessons and suggestions. Front Med. 2020; 14(2): 229-31. doi: 10.1007/s11684-020-0765-x.

\section{Correspondence to/Autor za korespondenciju}

Sina Ferahman, MD.

Adress: Bakirkoy Dr. Sadi Konuk Training and Research Hospital,

General Surgery Department Zuhuratbaba Mah, Dr. Tevfik Sağlam Cd No: 11, 34147 Bakırkoy/Istanbul/Turkey.

Phone: +90 5336120201

E-mail: sinaferahmantr@hotmail.com

Orcid no: 0000-0003-1160-9156 